\title{
The roles of ameliorants on tree seedling growth for land rehabilitation
}

\author{
SLAMET BUDI YUWONO $^{1, \boldsymbol{v}}$, ALAWIYAH ${ }^{2}$, MELYA RINIARTI ${ }^{1}$, DERMIYATI $^{\mathbf{3}}$ \\ ${ }^{1}$ Department of Forestry, Faculty of Agriculture, Universitas Lampung. J1. Sumantri Brojonegoro No. 1, Bandar Lampung 35145, Lampung, Indonesia. \\ Tel.: +62-721-701609, Fax .: +62-721-702767, `email: sbyuwono_unila@yahoo.com \\ ${ }^{2}$ Graduate Program of Forestry Science, Faculty of Agriculture, Universitas Lampung. Jl. Sumantri Brojonegoro 1, Bandar Lampung 35145, Lampung, \\ Indonesia \\ ${ }^{3}$ Department of Soil Science, Faculty of Agriculture, Universitas Lampung. J1. Sumantri Brojonegoro No. 1, Bandar Lampung 35145, Lampung, Indonesia
}

Manuscript received: 7 March 2021. Revision accepted: 20 April 2021.

\begin{abstract}
Yuwono SB, Alawiyah, Riniarti M, Dermiyati. 2021. The roles of ameliorants on tree seedling growth for land rehabilitation. Biodiversitas 22: 2706-2714. Revegetation of the limestone post-mining land using trees with ameliorants is expected to improve land quality and soil biodiversity. This research aimed to accelerate the seedling growth of tree species namely sengon (Paraserianthes falcataria), agarwood or gaharu (Aquilaria malaccensis), and acacia (Acacia mangium) on limestone post-mining soil media by applying various types of ameliorants. The experimental design was a Completely Randomized Design consisting of 7 treatments with three replications, namely P0 (without ameliorant or control), P1 (humic acid [HA], $4 \mathrm{~kg} \mathrm{ha}^{-1}$ ), P2 (phosphate rocks [PR], $350 \mathrm{~kg}$ ha ${ }^{-1}$ ), P3 (arbuscular mycorrhizal fungi [AMF], 500 spores plant ${ }^{-1}$ ), P4 (HA+AMF), P5 (PR+ AMF), and P6 (HA+PR+AMF). The variance analysis of data were done at the significance level of 0.05 and continued with the LSD test. The combination of ameliorants HA and AMF gave the highest root nodules number in 3-month-old $P$. falcataria with the percentage of effective nodules in absorbing $\mathrm{N}$ of $100 \%$ at 12 weeks after planting. Ameliorant application did not affect the root nodule number, the percentage of effective nodules, and the percentage of root infection by mycorrhizae in 3-month-old A. mangium. The combination of ameliorants PR and AMF gave the highest percentage of root infection by mycorrhizae in 4-month-old A. malaccensis. The tree dependence level on mycorrhizae was categorized as highly dependent on A. malaccensis, marginally dependent on P. falcataria, and independent on A. mangium.
\end{abstract}

Keywords: Ameliorant, arbuscular mycorrhizae, limestone, nodule, post-mining

\section{INTRODUCTION}

Limestone post-mining land is a degraded land with low soil fertility, characterized by low organic matter, mineral nutrients, and infective soil microorganisms. Prayudyaningsih (2014) states that the limestone mining process includes land clearing, drilling, blasting, pushing, and transportation, resulting in loss of vegetation and topsoil layers, low organic matter content and nutrient availability, soil compaction, high $\mathrm{pH}$, high soil temperature, and low diversity of microbes on the mined land.

Before the limestone mined land can be utilized optimally, the problem of soil fertility in this land must be resolved by rehabilitation, especially by revegetation activities. Suitable tree species and appropriate technology to improve soil fertility are required for a successful revegetation. Fast-growing tree species that are resistant to environmental stress are needed for revegetation of limestone post-mining land. Soil ameliorants are usually used to improve soil fertility.

Many studies show that humic acid (HA), arbuscular mycorrhizal fungi (AMF), and rock phosphates (RP) have positive effects on plant growth and the availability of soil nutrients (Omar 1997; Abdel-Mawgoud et al. 2007, Ghorbani et al. 2010, Smith and Read 2010). AbdelMawgoud et al. (2007) say that humic acid increases plant growth by chelating nutrients to overcome the lack of nutrients and has beneficial effects on growth, production, and quality improvement of agricultural products having hormonal compounds. The humic acid foliar spray has remarkable effects on the plant vegetative growth and increases photosynthetic activity and leaf area index of legumes (Ghorbani et al. 2010). The treatment with 100 ppm humic acid has sustained plant growth more than other treatments (Ayuso et al. 1996; Haghighi et al. 2011; Motaghi et al. 2014).

Moreover, AM fungi (AMF) infect plant roots of most species and form symbiosis with the plants under a wide variety of soil conditions (Smith and Read 2010). In this symbiosis, the plant provides carbon for AMF growth, and in turn, the AMF provides plant with nutrients, especially phosphorus (P), from the soil solution (Mosse 1973). In nutrient-poor environments, growth responses of host plants to infection by AMF are significant (Gerdemann 1975). Hyphae of mycorrhizae may also spread from one infected plant and enter one or more other plants (Heap and Newman 1980). It has been shown that assimilation may be transported from one plant to another through AMF hyphal connections.

Meanwhile, rock phosphates are categorized as lowgrade fertilizers because of their low $\mathrm{P}$ content. The utilization of rock phosphates as a substitute for a highgrade phosphorus fertilizer needs to be explored. Omar (1997) found that rock phosphate fertilization, and inoculation with Glomus constrictum, and rock-phosphatesolubilizing fungi (A. niger and $P$. citrinum) increased dry matter yield of wheat plants. Combining those HA, AMF, 
and RP as ameliorants are likely to affect tree seedlings growth. There are a lot of experimental data on the role of ameliorants in improving soil fertility and increasing crop production (Sindhu et al. 2016; Ghorbani et al. 2010; Smith and Read 2010; Baloyi et al. 2014; Sulakhudin et al. 2017). However, studies on the influence of ameliorants of HA, $\mathrm{AMF}$, and RP, and their combination on the development of root nodules, the association of arbuscular mycorrhizal fungi, and their ability to provide nutrients for plants, and their impact on soil chemical properties, especially in the nursery of various forestry tree species for the rehabilitation of degraded land after limestone mining in Indonesia are lacking.

This research aimed to study the growth of three tree seedlings (sengon, acacia, and agarwood/gaharu) through the development of root nodules and the association of arbuscular mycorrhizal fungi by administering various types of ameliorants in limestone post-mining soil.

\section{MATERIALS AND METHODS}

This research was conducted in the greenhouse of the Sumatra Institute of Technology (ITERA) Bandar Lampung, Indonesia. The study was designed in a completely randomized design with seven treatments of ameliorant, namely P0 (without ameliorant or control), P1 (humic acid, HA), P2 (phosphate rocks, PR), P3 (arbuscular mycorrhizal fungi, AMF), P4 (a combination of HA and AMF), P5 (a combination of PR and AMF), and P6 (a combination of HA, PR, and AMF). The research was repeated three times using six plants in each replication, so there were 126 experimental units for 1 species of plant, with a total of 378 experimental units. Data were checked for their homogeneity dan additivity. Because the data were homogenous and additive, then, the data were analyzed using variance analysis (ANOVA) at a 95\% confidence level, and continued with the Least Significant Difference (LSD) test using SAS software.
The tree species of seedlings used were 3-month-old sengon (Paraserianthes falcataria), 3-month-old acacia (Acacia mangium), 4-month-old agarwood (Aquilaria malaccensis) from the Permanent Nursery of the Watershed and Protected Forest Management Center Way Seputih-Way Sekampung (BPDASHL-WSS) in Kalianda, South Lampung (Figure 1).

The planting medium was a mixture of limestone soil from Mount Camang, Bandar Lampung, rice husks, cow manure, and topsoil $(0-20 \mathrm{~cm}$ depth) from the ITERA Botanical Garden. Based on our previous research, the use of post-mining soil only restricted tree growth due to very poor soil properties.

Limestone post-mining soil and topsoil were sieved using a $1 \mathrm{~cm} \times 1 \mathrm{~cm}$ sieve, and weighed to get $0.5 \mathrm{~kg}$ of soil for each sampling unit. After that, the soil was mixed with $0.5 \mathrm{~kg}$ of cow manure and $0.25 \mathrm{~kg}$ of rice husk and stirred until blended and put into the media until the weight for each treatment was $1.75 \mathrm{~kg}$ plant $^{-1}$. The growing media ratio of lime soil, topsoil, cow manure, and husk was 2: 2: 2: 1 [0.5 kg: $0.5 \mathrm{~kg}: 0.5 \mathrm{~kg}: 0.25 \mathrm{~kg}$ ], respectively. PR $(350 \mathrm{~kg}$ $\mathrm{ha}^{-1},\left[0.263 \mathrm{~g} \mathrm{plant}^{-1}\right)$ was applied to the media by mixing and stirring until blended, while HA $\left(4 \mathrm{~kg} \mathrm{ha}^{-1},[0.003 \mathrm{~g}\right.$ plant $\left.^{-1}\right]$ ) was dissolved in $4 \mathrm{~mL}$ of water, and then sprinkled on the planting medium. HA and PR applications were carried out one week before planting. AMF application (500 spores plant $^{-1}$ ) was a mixture of genera Glomus, Gigaspora, Acaulospora, and Entropospora. The AMF was obtained from Plant Science Laboratory of Lampung University.

The role of ameliorants in the growth of three tree seedlings was found by observing the development of root nodules, and the association of arbuscular mycorrhizal fungi in sengon, acacia, and agarwood seedlings. The observations were done on the number of root nodules, the percentage of effective root nodules, and the percentage of root infections by mycorrhizae until twelve weeks after application (WAP). Also, the value of relative mycorrhizal dependence (RMD), the percent growth response (PGR), and the mycorrhizal plant dependence on phosphorus (DPU) were calculated.

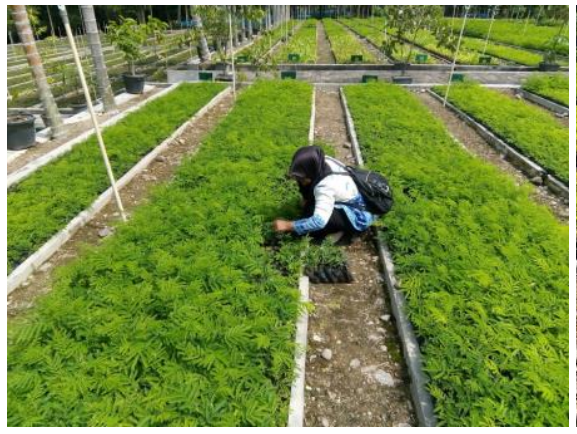

A

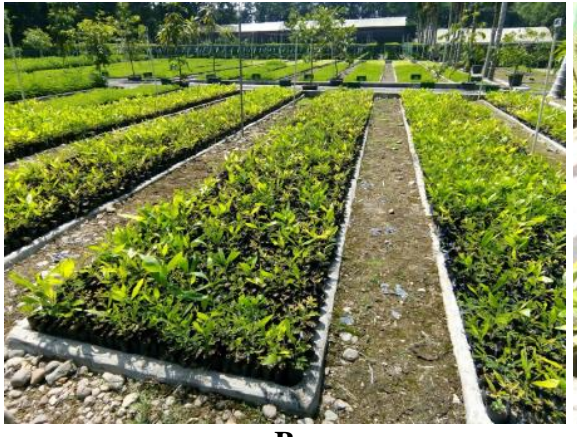

B

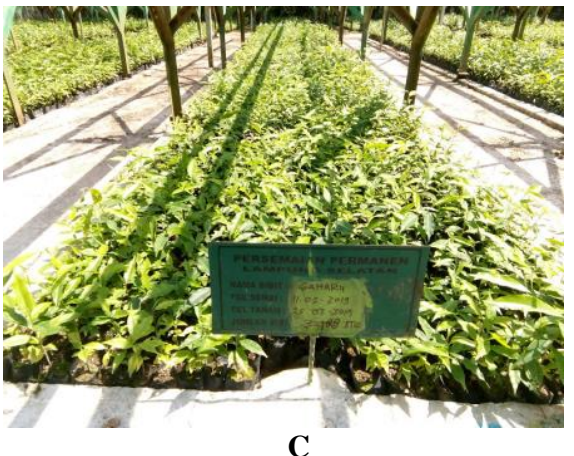

C

Figure 1. The seedlings of tree species used were: A. Sengon (Paraserianthes falcataria), B. Acacia (Acacia mangium), C. Agarwood (Aquilaria malaccensis) from the BPDASHL-WSS Permanent Nursery, Ketapang, South Lampung, Indonesia 
RMD was calculated based on Plenchette et al. (1983) as follows:

$\mathrm{RMD}=$ Dry weight of plant with mychorrizae - Dry weight of plant without mychorrizae $x$ 100\% Dry weight of plant with mychorrizae

RMD is categorized as very highly dependent (RMD > $75 \%$ ), highly dependent (RMD 50\%-75\%), moderatelly dependent (RMD 25\%-50\%), dan marginally dependent (RMD 0-25\%) (Habte dan Manajunath 1991).

PGR was calculated based on Hetrik, Wilson, and Cox (1993) as follows:

PGR $=$ Dry weight of innoculated plant - Dry weight of non-innoculated plant $x 100 \%$ Dry weight of non-innoculated plant

DPU was calculated based on Tawaraya et al. (2001) as follows:

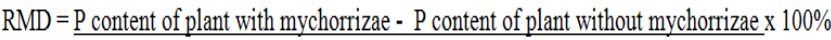
$P$ content of plant with mychorrizae

\section{RESULTS AND DISCUSSION}

The results of the analysis of variance showed that the use of ameliorants had a significant effect on the root nodule number, and the percentage of effective nodules in sengon and acacia seedlings for the entire observation period, except for the percentage of effective root nodules at 12 WAP. However, agarwood seedlings did not contain nodules. Furthermore, the ameliorants application affected the percent root infections of mycorrhizae in the three tree species (Table 1).

\section{Number of root nodules}

The use of ameliorants had a significant effect on the number of root nodules of sengon and acacia at all observation times (Table 2). The difference in the nodule number in the two tree species is shown in Figure 2.

Table 1. Recapitulation of significance of variance analysis of all observed variables for three tree species

\begin{tabular}{|c|c|c|c|}
\hline Variable & Sengon & Acacia & Agarwood \\
\hline Number of nodules (4 WAP) & $*$ & $*$ & NA \\
\hline Number of nodules ( 8 WAP) & $*$ & $*$ & NA \\
\hline Number of nodules (12 WAP) & $*$ & $*$ & NA \\
\hline Percentage of effective root nodules (4 WAP) & $*$ & $*$ & NA \\
\hline Percentage of effective root nodules ( 8 WAP) & $*$ & $*$ & NA \\
\hline Percentage of effective root nodules (12 WAP) & ns & ns & NA \\
\hline Percent root infection by mycorrhizae (4 WAP) & $*$ & $*$ & $*$ \\
\hline Percent root infection by mycorrhizae ( 8 WAP) & $*$ & $*$ & $*$ \\
\hline Percent root infection by mycorrhizae (12 WAP) & $*$ & $*$ & $*$ \\
\hline
\end{tabular}

Note : *: Significantly different at P<0.05; ns: not significantly different; NA: Not Available; WAP: Week After Planting.

Table 2. Effect of ameliorants on the nodules number of sengon and acacia seedlings

\begin{tabular}{llll}
\hline \multirow{2}{*}{ Ameliorant treatment } & \multicolumn{3}{c}{ Number of root nodules (units) } \\
\cline { 2 - 4 } Sengon seedlings & $\mathbf{4}$ WAP* & $\mathbf{8 ~ W A P *}$ & $\mathbf{1 2}$ WAP* \\
Control (P0) & $144 \pm 5.20^{\mathrm{b}}$ & $313 \pm 6.35^{\mathrm{a}}$ & $253.33 \pm 9,53^{\mathrm{a}}$ \\
HA (P1) & $161.33 \pm 6.64^{\mathrm{a}}$ & $263.33 \pm 39.55^{\mathrm{ab}}$ & $252 \pm 5.77^{\mathrm{b}}$ \\
PR (P2) & $110 \pm 4.04^{\mathrm{c}}$ & $187 \pm 6.93^{\mathrm{c}}$ & $290 \pm 1.73^{\mathrm{ab}}$ \\
AMF (P3) & $91 \pm 2.89^{\mathrm{d}}$ & $181.33 \pm 0.33^{\mathrm{c}}$ & $193 \pm 12,702^{\mathrm{c}}$ \\
HA and AMF (P4) & $155.33 \pm 80^{\mathrm{ab}}$ & $203.33 \pm 25.11^{\mathrm{bc}}$ & $302.33 \pm 22.81^{\mathrm{a}}$ \\
PR and AMF (P5) & $100.33 \pm 0.33^{\mathrm{cd}}$ & $291 \pm 29.44^{\mathrm{a}}$ & $82.33 \pm 11.26^{\mathrm{d}}$ \\
HA, PR, and AMF (P6) & $109.33 \pm 2.03^{\mathrm{c}}$ & $97.33 \pm 11.26^{\mathrm{d}}$ & $253.33 \pm 28.58^{\mathrm{b}}$ \\
LSD (0.05) & 14.54 & 65.63 & 47.99 \\
Acacia seedlings & & $35.67 \pm 0.33^{\mathrm{a}}$ & \\
Control (P0) & $8.67 \pm 0.33^{\mathrm{d}}$ & $28 \pm 1.15^{\mathrm{b}}$ & $115.33 \pm 3.76^{\mathrm{a}}$ \\
HA (P1) & $23 \pm 3.46^{\mathrm{b}}$ & $18.33 \pm 0.88^{\mathrm{c}}$ & $68 \pm 5.20^{\mathrm{c}}$ \\
PR (P2) & $14.33 \pm 1.45^{\mathrm{c}}$ & $11 \pm 1.73^{\mathrm{d}}$ & $58 \pm 11.55^{\mathrm{cd}}$ \\
AMF (P3) & $37.33 \pm 1.45^{\mathrm{a}}$ & $19 \pm 1.15^{\mathrm{c}}$ & $25 \pm 2.31^{\mathrm{e}}$ \\
HA and AMF (P4) & $16 \pm 1.16^{\mathrm{c}}$ & $27 \pm 1.73^{\mathrm{b}}$ & $49 \pm 1.73^{\mathrm{d}}$ \\
PR and AMF (P5) & $28.33 \pm 1.45^{\mathrm{b}}$ & $31 \pm 4.04^{\mathrm{ab}}$ & $41 \pm 1.73^{\mathrm{de}}$ \\
HA, PR and AMF (P6) & $12.33 \pm 1.45^{\mathrm{cd}}$ & 5.83 & $87 \pm 6.93^{\mathrm{b}}$
\end{tabular}

Note: Values followed by different letters in the same column are significantly different, determined with LSD at 0.05 significance level; *Average value $\pm \mathrm{SE}$ 


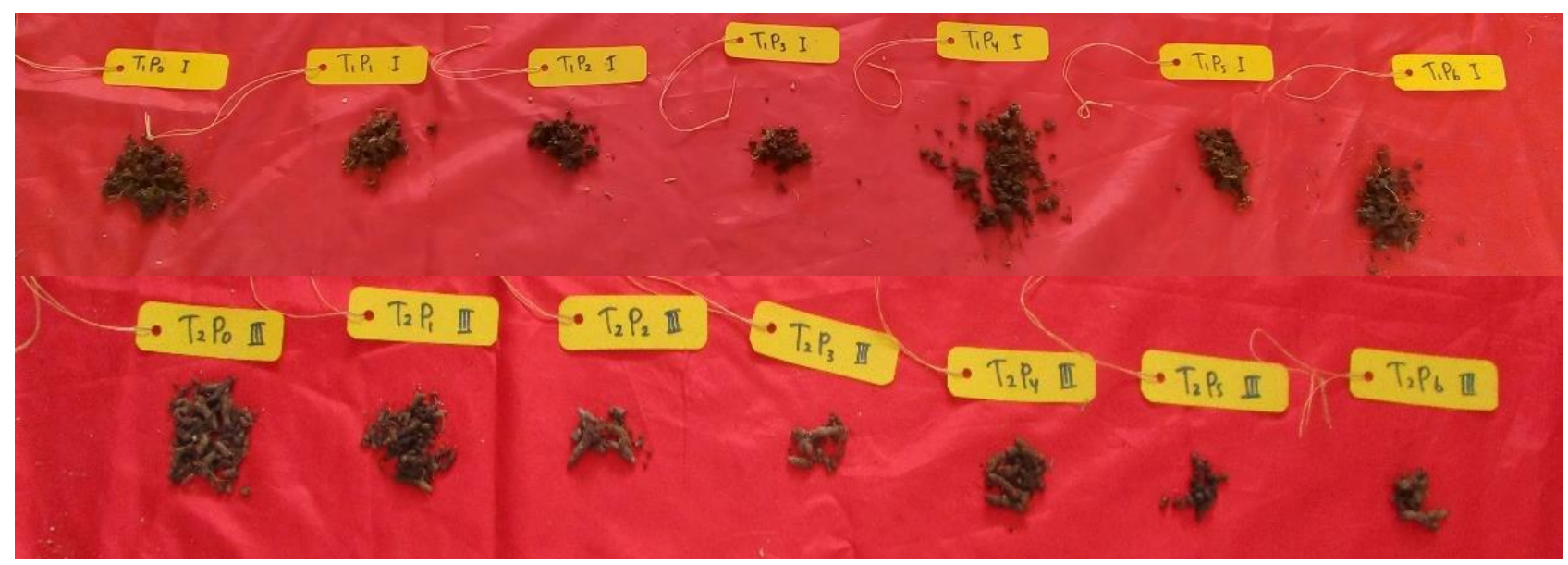

Figure 2. Difference in the roots nodules number of sengon (top) and acacia (bottom)

In sengon, the highest number of nodules was obtained in the combination of HA and AMF treatment. Humic acid can increase microorganism activity in the soil by increasing the rhizobium activity to form root nodules, while AMF helps the Rhizobium sp. in fixing nitrogen from the atmosphere, and help the roots in absorbing other macro and micronutrients (Nadeem et al. 2014). It was rare to find root nodules on hard soil with a little hummus or even none at all. Humic acid plays a vital role in the formation of root nodules. The humic acid increases soil biological activities by increasing root infection by AMF and Rhizobium. Research by Budiastuti et al. (2020) found that mycorrhizae and rhizobium had a synergistic relationship to nodulation and root growth of Indigofera tinctoria. AMF inoculation promoted root nodule formation, while Rhizobium inoculation increased the percentage of AMF infections (Gage 2004). There is a known symbiotic relationship between mycorrhizae and Rhizobium in Phaseolus vulgaris (Mortimer et al. 2012) and Vicia faba (Abd-Alla et al. 2014). Moreover, mycorrhizae and Rhizobium can increase plant growth by regulating the balance of nutrients and hormones; as growth regulators, they dissolve nutrients and induce resistance to plant pathogens. Besides, these microbes also show synergistic interactions with other microbes in the soil environment (Nadeem et al. 2014)

Factors that influence nodules formation are microsymbionts (Rhizobium), macrosymbionts (legumes), and environmental factors, i.e., the physical, biological, and chemical factors. Rhizobium plays a role in binding $\mathrm{N}$, but if there is enough $\mathrm{N}$ available in the soil, it cannot work optimally to fix $\mathrm{N}$, because $\mathrm{N}$ is already available and the process of forming nodules will also decrease. Streeter (1988) states that in the presence of high concentrations of combined nitrogen (i.e., nitrate, ammonium), plants do not need $\mathrm{N}$-fixation, and nodule formation is suppressed.

The highest number of root nodules in acacia was found in the treatment without ameliorants (Figure 2). The research by Aprillia et al. (2019) found that the highest number of root nodules in acacia was $100 \%$ soil without mycorrhizae treatment, followed by $50 \%$ soil $+50 \%$ lime tailings without mycorrhizae. This indicates that more acacia root nodules will form in soil without mycorrhizae. Cardinale et al. (2010) found root colonization by AMF after nine months of growth, revealing that unknown indigenous AMF colonized uninoculated plants. The development phase of an acacia root nodule is shown in Figure 3.

Root nodules were formed in all treatments in sengon and acacia seedlings. The number of nodules in sengon at 12 WAP ranged from 82 to 302 units. Sengon nodule belongs to the indeterminate type which has many branches (Figure 3). The number of nodules in acacia at 12 WAP ranged from 25 to 115 . Acacia root nodules only have 2 - 3 branches on each nodule (Figure 3). There are two types of root nodules, namely determinate and indeterminate, referring to the absence or presence of a persistent meristem (Oldroyd et al. 2011). The determinate nodule is oval, while the indeterminate nodule has an axis, and it is elongated by the meristem at the apical part of the nodule (Puppo et al. 2005). Moreover, Oldroyd et al. (2011) state that in both nodule types, bacteria have to gain access to the root interior, and invade the nodule primordium internal tissues. The root infection occurs via the formation of a plant-derived tubular structure and the intracellular delivery of the bacteria through endocytosis and subsequent differentiation into the microsymbiont bacteroid nitrogenfixing form.

\section{Percentage of effective root nodules}

The use of ameliorants had a significant effect on the percentage of effective root nodules of sengon and acacia at 4 WAP and 8 WAP (Table 3). There was a difference in the rate of effective nodules at $4 \mathrm{WAP}$ and $8 \mathrm{WAP}$, but at 12 WAP, all root nodules were $100 \%$ effective. Observation of the percentage of effective nodules was carried out by cutting the nodules in half and visually seeing the color of the root nodules that had been cut (Figure 4). 
Effective root nodules are root nodules containing the red or pink pigment of leghemoglobin (Kukkamalla and Vardhan 2016; Howieson et al. 2016), which functions to regulate the entry of oxygen into the bacteroid, so at the optimum position, the $\mathrm{N}$ fixation process can take place well. The characteristic of ineffective root nodules is black color due to the aging of the nodules. After a nitrogen fixation period, the tissues decay or the nodules turn to light green, and are thought to be no longer active in fixing $\mathrm{N}$ (Howieson et al. 2016). The increasing number of effective root nodules will increase $\mathrm{N}$ binding, which plays a role in forming chlorophyll and enzymes to improve the photosynthetic process, increasing the vegetative and generative growth of host plants (Surtiningsih 2009).
Franzini et al. (2019) mention that Rhizobium symbiosis with legumes affects plant root hydraulic characteristics: Rhizobium symbiosis causes a decrease of osmotic potential of xylem sap, so the root osmotic water flow increases, and rhizobium inoculation increases plant growth.

\section{Percentage of root infection by AMF}

The ameliorants significantly affected the percentage of root infection by mycorrhizae in sengon, acacia, and agarwood seedlings for the entire observation time (Table 4).

Table 3. Effect of ameliorants on the percentage of effective root nodules in sengon and acacia tree seedlings

\begin{tabular}{|c|c|c|c|}
\hline \multirow{2}{*}{ Ameliorant treatment } & \multicolumn{3}{|c|}{ Percentage of effective root nodules (\%) } \\
\hline & 4 WAP * & 8WAP * & $12 \mathrm{WAP} *$ \\
\hline \multicolumn{4}{|l|}{ Sengon seedlings } \\
\hline Control (P0) & $94.52 \pm 3.02^{\mathrm{b}}$ & $100 \pm 0.00^{\mathrm{a}}$ & $100 \pm 0.00^{\mathrm{a}}$ \\
\hline HA (P1) & $90.3 \pm 0.85^{c}$ & $87.5 \pm 7.22^{\mathrm{b}}$ & $100 \pm 0.00^{\mathrm{a}}$ \\
\hline $\mathrm{PR}(\mathrm{P} 2)$ & $99 \pm 0.58^{\mathrm{a}}$ & $100 \pm 0.00^{\mathrm{a}}$ & $100 \pm 0.00^{\mathrm{a}}$ \\
\hline $\mathrm{AMF}(\mathrm{P} 3)$ & $81.18 \pm 0.74^{\mathrm{d}}$ & $99 \pm 0.577^{\mathrm{a}}$ & $100 \pm 0.00^{\mathrm{a}}$ \\
\hline HA and AMF (P4) & $100 \pm 0.00^{\mathrm{a}}$ & $87.50 \pm 1,443^{\mathrm{b}}$ & $100 \pm 0.00^{\mathrm{a}}$ \\
\hline PR and AMF (P5) & $100 \pm 0.00^{\mathrm{a}}$ & $100 \pm 0.00^{\mathrm{a}}$ & $100 \pm 0.00^{\mathrm{a}}$ \\
\hline $\mathrm{HA}, \mathrm{PR}$ and $\mathrm{AMF}(\mathrm{P} 6)$ & $100 \pm 0.00^{\mathrm{a}}$ & $95 \pm 2,887^{\text {ab }}$ & $100 \pm 0.00^{\mathrm{a}}$ \\
\hline $\operatorname{LSD}(0.05)$ & 3.75 & 9.09 & \\
\hline \multicolumn{4}{|l|}{ Acacia seedlings } \\
\hline Control (P0) & $100 \pm 0.00^{\mathrm{a}}$ & $100 \pm 0.00^{\mathrm{a}}$ & $100 \pm 0.00^{\mathrm{a}}$ \\
\hline $\mathrm{HA}(\mathrm{P} 1)$ & $99.23 \pm 0.39 b$ & $100 \pm 0.00^{\mathrm{a}}$ & $100 \pm 0.00^{\mathrm{a}}$ \\
\hline $\mathrm{PR}(\mathrm{P} 2)$ & $100 \pm 0.00^{\mathrm{a}}$ & $100 \pm 0.00^{\mathrm{a}}$ & $100 \pm 0.00^{\mathrm{a}}$ \\
\hline $\mathrm{AMF}(\mathrm{P} 3)$ & $100 \pm 0.00^{\mathrm{a}}$ & $100 \pm 0.00^{\mathrm{a}}$ & $100 \pm 0.00^{\mathrm{a}}$ \\
\hline HA and AMF (P4) & $100 \pm 0.00^{\mathrm{a}}$ & $100 \pm 0.00^{\mathrm{a}}$ & $100 \pm 0.00^{\mathrm{a}}$ \\
\hline PR and AMF (P5) & $100 \pm 0.00^{\mathrm{a}}$ & $95 \pm 2.887 \mathrm{~b}$ & $100 \pm 0.00^{\mathrm{a}}$ \\
\hline $\mathrm{HA}, \mathrm{PR}$ and AMF (P6) & $100 \pm 0.00^{\mathrm{a}}$ & $100 \pm 0.00^{\mathrm{a}}$ & $100 \pm 0.00^{\mathrm{a}}$ \\
\hline $\operatorname{LSD}(0.05)$ & 0.45 & 3.31 & \\
\hline
\end{tabular}

Note: Values followed by different letters in the same column are significantly different, determined with LSD at 0.05 significance level; *Average value \pm SE.

Table 4. Percentage of root infections by mycorrhizae in sengon, acacia, and agarwood (\%)

\begin{tabular}{|c|c|c|c|}
\hline \multirow{2}{*}{ Ameliorant treatment } & \multicolumn{3}{|c|}{ Percentage of root infection by mycorrhizae } \\
\hline & 4 WAP* & 8 WAP* & 12 WAP* \\
\hline \multicolumn{4}{|l|}{ Sengon seedlings } \\
\hline $\mathrm{AMF}$ & $24.87 \pm 6.54^{\mathrm{b}}$ & $10.655 \pm 1.76^{\mathrm{c}}$ & $8.43 \pm 2.94^{\mathrm{c}}$ \\
\hline $\mathrm{HA}$ and $\mathrm{AMF}$ & $20.16 \pm 9.35^{b}$ & $12.31 \pm 0.11^{\mathrm{c}}$ & $22.87 \pm 0.37^{\mathrm{a}}$ \\
\hline $\mathrm{PR}$ and $\mathrm{AMF}$ & $49.68 \pm 2.07^{\mathrm{a}}$ & $48.77 \pm 1.43^{\mathrm{a}}$ & $16.40 \pm 1.15^{\mathrm{b}}$ \\
\hline $\mathrm{HA}, \mathrm{PR}$ and $\mathrm{AMF}$ & $16.05 \pm 0.18^{\mathrm{b}}$ & $16.41 \pm 0.56^{\mathrm{b}}$ & $27.40 \pm 2.13^{\mathrm{a}}$ \\
\hline $\operatorname{LSD}(0.5)$ & 18.92 & 3.82 & 6.24 \\
\hline \multicolumn{4}{|l|}{ Acacia seedlings } \\
\hline $\mathrm{AMF}$ & $38.69 \pm 4.80^{\mathrm{a}}$ & $23.34 \pm 0.20 \mathrm{a}$ & $23.73 \pm 0.23^{\mathrm{b}}$ \\
\hline $\mathrm{HA}$ and $\mathrm{AMF}$ & $35.05 \pm 0.67^{\mathrm{a}}$ & $6.36 \pm 2.74 c$ & $12.53 \pm 1.46^{\mathrm{c}}$ \\
\hline $\mathrm{PR}$ and $\mathrm{AMF}$ & $35.54 \pm 3.54^{\mathrm{a}}$ & $16.6 \pm 0.11 b$ & $29.43 \pm 0.56^{\mathrm{a}}$ \\
\hline $\mathrm{HA}, \mathrm{PR}$ and $\mathrm{AMF}$ & $7,345 \pm 1.28^{b}$ & $18.42 \pm 2.86 \mathrm{ab}$ & $18.62 \pm 0.01^{\mathrm{c}}$ \\
\hline $\operatorname{LSD}(0.5)$ & 10.01 & 6.48 & 2.58 \\
\hline \multicolumn{4}{|l|}{ Agarwood seedlings } \\
\hline AMF & $46.755 \pm 3.57^{\mathrm{a}}$ & $26.05 \pm 2.33^{\mathrm{a}}$ & $35.22 \pm 1.09 b$ \\
\hline $\mathrm{HA}$ and $\mathrm{AMF}$ & $53.33 \pm 1,022^{\mathrm{a}}$ & $15.78 \pm 1.71^{b}$ & $28.22 \pm 0.79 c$ \\
\hline $\mathrm{PR}$ and $\mathrm{AMF}$ & $21.96 \pm 1,129^{\mathrm{b}}$ & $14.82 \pm 0.51^{\mathrm{b}}$ & $39.97 \pm 1.87 \mathrm{a}$ \\
\hline $\mathrm{HA}, \mathrm{PR}$ and $\mathrm{AMF}$ & $24.58 \pm 1.72^{\mathrm{b}}$ & $8.17 \pm 2.38^{c}$ & $25.93 \pm 1.06 \mathrm{c}$ \\
\hline $\operatorname{LSD}(0.5)$ & 6.92 & 6.17 & 4.14 \\
\hline
\end{tabular}

Note: Values followed by different letters in the same column are significantly different, determined with LSD at 0.05 significance level; *Average value \pm SE. 


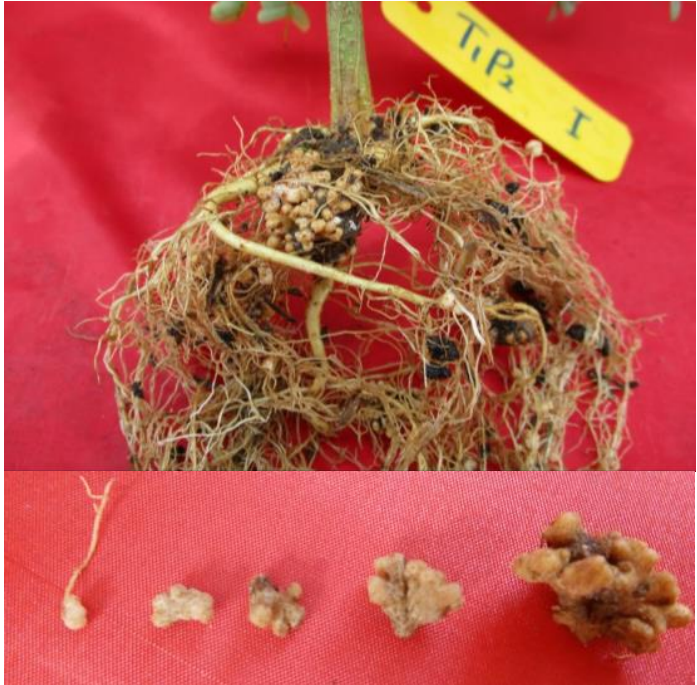

A

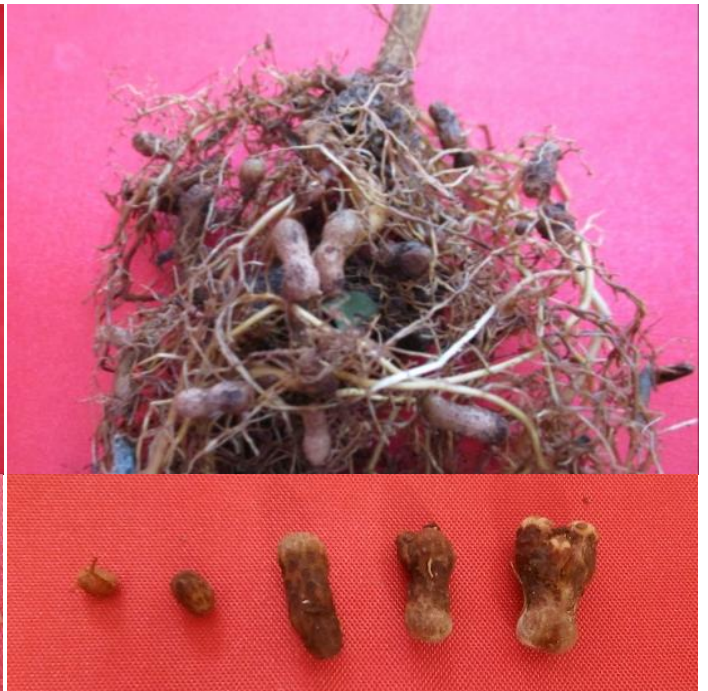

B

Figure 3. Developmental phases root nodules of sengon (A) and acacia (B)

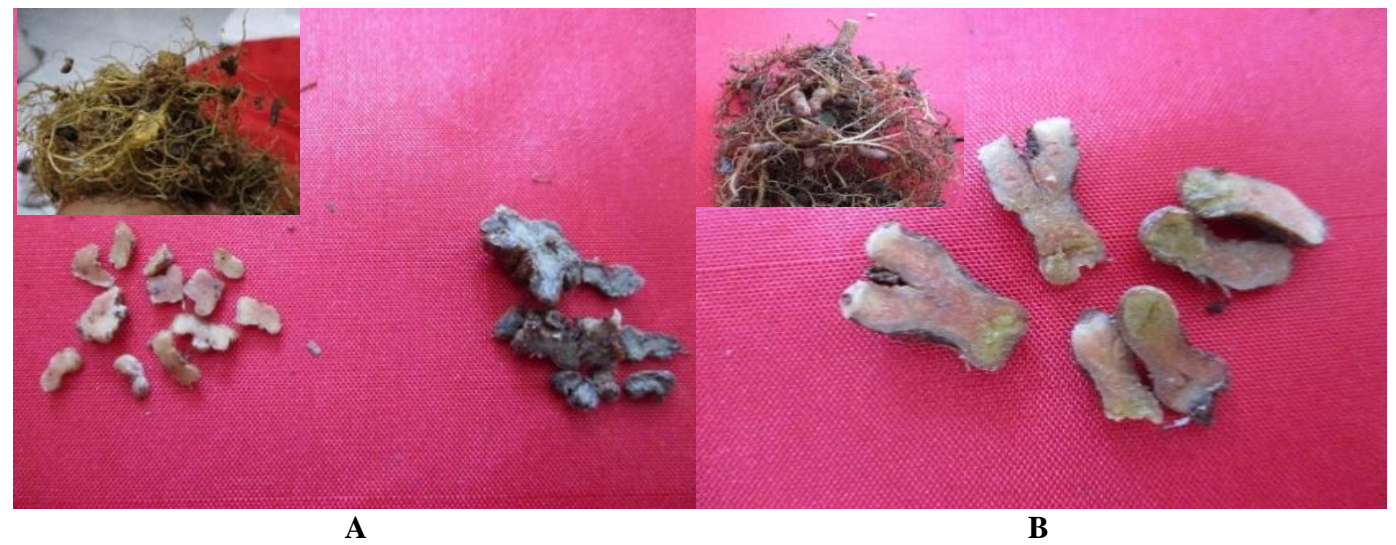

Figure 4. Difference between sengon (A) and acacia (B) root nodules

The highest percentage of root infection by mycorrhizae in sengon seedlings at 12 WAP was found in the combination of $\mathrm{HA}+\mathrm{PR}+\mathrm{AMF}(27.41 \%)$, but not significantly different from the combination treatment HA+AMF (22.87\%). Meanwhile, the highest percentage of infection in acacia seedlings was found in the combination of PR+AMF (29.43\%), and the most considerable infection rate in agarwood seedlings was found in the combination of PR+AMF (39.97\%).

Abdel-Mawgoud et al. (2007) state that humic acid increases plant growth by various chelating nutrients to overcome the lack of nutrients and has beneficial effects on the development, production, and quality improvement of agricultural products having hormonal compounds. Husna et al. (2021) found that the range of mycorrhizae inoculation effect values of 4-month-old Kalapi seedlings (Kalappia celebica) was 59.7-71.3\%, and AMF inoculation increased the growth and dry weight of Kalapi compared to controls.

Mycorrhizal root infections in host plants are influenced by several factors: the host plant age, nutrients, planting practices, climatic factors, and soil factors. Mycorrhizae will more easily infect young plants that are in the stage of root formation. Moreover, AM fungi influence the mineral nutrition of the host plant, and the most pronounced effect is the enhancement of phosphate absorption from nutrientpoor sources (Smith and Gianinazzi-Pearson 1988).

The AMF infection percentage of sengon seedlings with $\mathrm{HA}+\mathrm{PR}+\mathrm{AMF}$ application, and acacia and agarwood seedlings with PR and AMF application were higher than that in other treatments. Mycorrhizae will grow well if the soil conditions are good, while humic acid plays a role in improving the physical, biological, and chemical properties of soil. The addition of PR also plays a role in increasing the availability of soil $\mathrm{P}$. The combination of these three types of ameliorants provided the highest percentage of root infections in sengon seedlings. The study of Sindhu et al. (2016) found that the combination of organic fertilizer and mycorrhizae increased growth of Indigofera tinctoria, indican content, nitrogen, and potassium content in the soils. 
The roots of plants without mycorrhizal application were also infected with AMF (Table 5), presumably due to the presence of mycorrhizae in the planting media or the plants were infected by mycorrhizae during the germination and weaning phases in the BPDASHL WSS nursery because mycorrhizal hyphae are naturally present in the soil. Cardinale et al. (2010) also reported that unknown indigenous AMF colonized uninoculated plants after nine months of growth.

\section{Relative Mycorrhizal Dependency (RMD), Percent Growth Response (PGR), and Dependency of P Uptake (DPU)}

The RMD, PGR, and DPU values were calculated to determine the dependence of plants on mycorrhizae. The results showed that plants dependence on mycorrhizae was not the same in sengon, acacia, and agarwood at 12 WAP (Table 6).

These three values are strongly influenced by the type of AMF given or controlled by the host plant species (Asmarhaman 2018). The sengon seedlings had an RMD value of $6.012 \%$ (marginally dependent), a PGR value $0 \%$, and a DPU value $15.746 \%$, while the acacia seedlings had an RMD value of $-45.212 \%$, PGR value $0 \%$, and DPU value $-9.554 \%$, and the agarwood seedlings had an RMD value of $60.173 \%$ (highly dependent), a PGR value $0 \%$, and a DPU value 6.944\%. Husna et al. (2021) found AMF inoculation increased the growth and dry weight of 4 - month-old seedlings Kalapi (Kalappia celebica) compared to controls, ranging from $59.7 \%$ to $71.3 \%$. Furthermore, the PGR value obtained was $0 \%$ for the three tree species tested because all plants, whether given mycorrhizae or not, were infected with mycorrhizae.

Agarwood had the highest dependence value on AMF compared to the other two species. With a highly dependent level on AMF, the level of dependence of plants on nutrient $\mathrm{P}$ is low. The growth of agarwood is highly dependent on its association with mycorrhizae, and vice versa. The inoculated AMF is very suitable to develop in agarwood. Mycorrhizal association with host plants plays a role in improving soil structure, increasing nutrient solubility, weathering the parent material, increasing water and nutrient uptake, and protecting plants from root pathogens and toxic elements (Hajoeningtijas 2009). A high RMD value is an indicator of increased growth and plant biomass growth (Asmahaman 2018).

Table 5. Mean percentage of root infections by mycorrhizae in plants without ameliorants

\begin{tabular}{llll}
\hline Tree species & $\mathbf{4}$ WAP* & 8 WAP* & 12 WAP* \\
\hline Sengon & $23.94 \pm 4.39$ & $35.43 \pm 11.62$ & $16.65 \pm 5,56$ \\
Acacia & $30.59 \pm 10.30$ & $18.83 \pm 1.66$ & $22.27 \pm 12.02$ \\
Agarwood & $37.85 \pm 5.15$ & $26.09 \pm 8.52$ & $14.00 \pm 3.55$ \\
\hline
\end{tabular}

Note: *Average value \pm SE.

Table 6. Average values of relative mycorrhizal dependence (RMD), percent growth response (PGR), and dependence on phosphorus (DPU) in the three tree species

\begin{tabular}{lccccc}
\hline Tree species & $\begin{array}{c}\text { Plant with mycorrhizae DW } \\
(\mathbf{g})\end{array}$ & $\begin{array}{c}\text { Plant without mycorrhizae DW } \\
(\mathbf{g})\end{array}$ & $\begin{array}{c}\text { RMD } \\
(\boldsymbol{\%})\end{array}$ & $\begin{array}{c}\text { PGR } \\
(\boldsymbol{\%})\end{array}$ & $\begin{array}{c}\text { DPU } \\
(\boldsymbol{\%})\end{array}$ \\
\hline Sengon (T1) & 48.854 & 45.917 & 6.012 & 0 & 15.746 \\
Acacia (T2) & 13.554 & 19.682 & -45.212 & 0 & -9.554 \\
Agarwood (T3) & 3.754 & 1.495 & 60.173 & 0 & 6.944 \\
\hline
\end{tabular}

Note: DW: Dry Weight, RMD: Relative Mycorrhizal Dependency, PGR: Percent Growth Response, DPU: Dependency of P Uptake

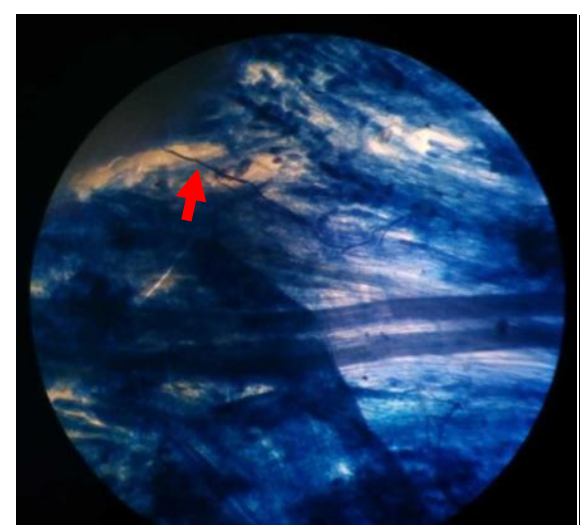

A

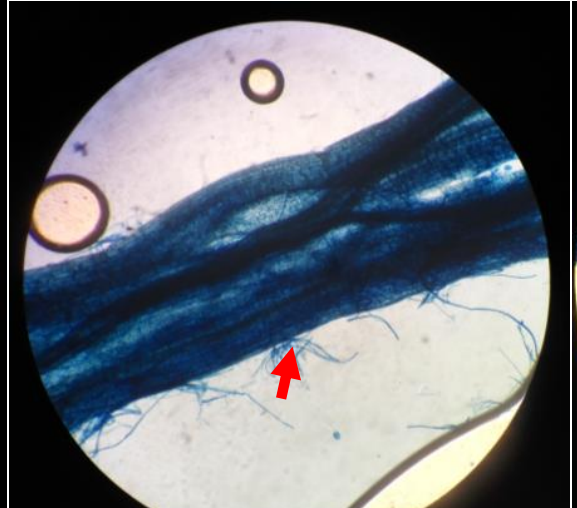

B

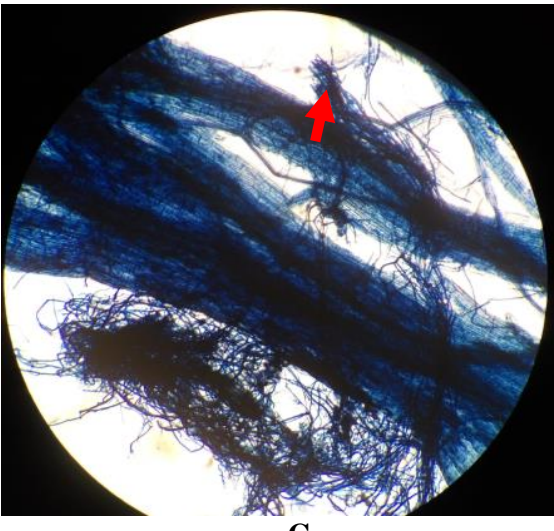

C

Figure 5. The roots of sengon (A), acacia (B), and agarwood (C) infected with mycorrhizae (magnifier 10 X 10). Red arrow: hyphae 
The dependence value of the sengon growth on mycorrhizae was very low (marginally dependent), with the value of reliance on phosphorus was also low. The growth of sengon seedlings does not depend on their association with mycorrhizae. Mycorrhizae play a role in the growth of sengon but do not significantly affect the growth. The effectiveness of AMF is very much determined by three factors, namely the type of AMF, the species of host plant, and the type of soil used (Ancient et al. 2014). Different soil types, AMF types, and host plants will result in different mycorrhizal dependence values.

Acacia seedling growth was not affected by plant symbiosis with AMF as seen from negative RMD and DPU. The acacia seedlings without AMF inoculation showed much better growth performance than those with AMF inoculation. Although AMF infected acacia roots their presence did not negatively affect acacia growth. It is suggested that growing acacia on the post-mining soil of Bukit Camang limestone does not require AMF inoculation. This study concluded that the role of ameliorants in the growth of sengon, acacia and agarwood seedlings was different among the three plant species.

\section{ACKNOWLEDGEMENTS}

We are very grateful to the University of Lampung, Indonesia for funding this research through the Lampung University Graduate Grant program. We also thank the Faculty of Agriculture, the University of Lampung, and the Institute of Technology Sumatra for facilitating this research. Thank also goes to Dr. Christine Wulandari and Dr. Asmarahman for valuable suggestions to the manuscripts.

\section{REFERENCES}

Abd-Alla MH, El-Enany AWE, Nafady NA, Khalaf DM, Morsy FM 2014. Synergistic interaction of Rhizobium leguminosarum bv. viciae and arbuscular mycorrhizal fungi as a plant growth-promoting biofertilizers for faba bean (Vicia faba L.) in alkaline soil. Microbiol Res 169 (1): 49-58. DOI: 10.1016/j.micres.2013.07.007.

Abdel-Mawgoud A, El-Greadly MRN, Helmy YI, Singer SM. 2007. Responses of tomato plants to different rates of humic-based fertilizer and NPK fertilization. J Appl Sci Res 3 (2): 169-174.

Aprillia D, Riniarti M, Bintoro A. 2019. Aplikasi ektomikoriza pada media tanam bekas tambang kapur untuk membantu pertumbuhan Mangium (Acacia mangium). Jurnal Sylva Lestari 7 (3): 332-341. DOI 10.23960/js137332-341. [Indonesian]

Asmarahman C. 2018. Pemanfaatan Fungi Mikoriza Arbuskular (FMA) dan Bahan Amelioran Tanah dalam Upaya Rehabilitasi Lahan Pascatambang PT. Holcim Indonesia TBK. [Disertasi]. Sekolah Pacasarjana, Institut Pertanian Bogor, Bogor. [Indonesian]

Ayuso M, Hernandez T, Gercia C. 1996. Effect of humic fraction from urban wastes and other more developed organic materials on seed germination. J Sci Food Agric 72 (4): 461-468. DOI 10.1002/(SICI)10970010(199612)72:4.

Baloyi TC, Du Preez CC, Kutu FR. 2014. Soil Ameliorants to improve soil chemical and microbial biomass properties in some South African soils. J Agric Sci 9 (2): 58-68. DOI: 10.4038/jas.v9i2.6908

Begum N, Qin C, Ahanger MA, Raza S, Khan MI, Ashraf M, Ahmed N and Zhang L. 2019. Role of arbuscular Mycorrhizal Fungi in Plant Growth Regulation: Implications in Abiotic Stress Tolerance. Front. Plant Sci. 10:1068. DOI: 10.3389/fpls.2019.01068
Budiastuti MS, Purnomo D, Supriyono, Pujiasmanto B, Desy S. 2020. Effects of light intensity and co-inoculation of arbuscular mycorrhizal fungi and Rhizobium on root growth and nodulation of Indigofera tinctoria. J Soil Sci Agroclimatol 17 (2): 94-99. DOI: 10.20961/stjssa.v17i2.40065.

Franzini VI, Azcón R., Ruiz-Lozano JM, Aroca R. 2019. Rhizobial symbiosis modifies root hydraulic properties in bean plants under non-stressed and salinity-stressed conditions. Planta 249 (4): 12071215. DOI: 10.1007/s00425-018-03076-0.

Gage DJ. 2004. Infection and invasion of roots by symbiotic, nitrogenfixing Rhizobia during nodulation of temperate legumes. Microbiol Mol Biol Rev 68 (2): 280-300. DOI: 10.1128/MMBR.68.2.280300.2004.

Gerdemann JW. 1975. Vesicular-arbuscular mycorrhizae. In: Torrey JG, Clarkson DT (eds) The Development and Function of Roots. Academic Press, New York.

Ghorbani S, Khazaei HR, Kafi M, Banayan AM. 2010. The effect of adding humic acid to irrigation water on yield and yield components of corn. J Agric Ecol 2: 123-131.

Habte M, Manjunath A. 1991. Categories of vesicular-arbuscular mycorrhizal dependency of host species. Mycorrhiza 1: 3-12.

Haghighi S, Nejab TS, Lack SH. 2011. Evaluation of changes the qualitative and quantitative yield of horse bean (Vicia faba L.) plant in the levels of humic acid fertilizer. Life Sci J 8 (3): 583-588.

Hajoeningtijas OD. 2009. Dependence of plants on mycorrhiza as a study of the potential of mycorrhiza biofertilizer in sustainable plant cultivation. Agritech 9 (2): 125-136.

Heap AJ, Newman EI. 1980. Links between roots by hyphae of vesiculararbuscular mycorrhizas. New Phytol 85 (2): 169-171. DOI: 10.1111/j.1469-8137.1980.tb04457.x

Howieson JG, Dilworth MJ. 2016. Working with Rhizobia. Australian Center for International Agricultural Research, Canberra.

Husna, Tuheteru FD, Arif A. 2021. The potential of arbuscular mycorrhizal function to conserve Kalappia celebica, an endangered endemic legume on gold mine tailings in Sulawesi, Indonesia. J For Res 32: 675-682. DOI: 10.1007/s11676-020-01097-8.

Kukkamalla A, Vardhan ZV. 2016. A study on effective and ineffective root nodules of Trigonella foenum-graecum Elicited by Bradyrhizobium. IOSR J Environ Sci Toxicol Food Technol (IOSRJESTFT) 10 (11): 106-111. DOI: 10.9790 / 2402-101101106111.

Cardinale M, Brusetti L, Lanza A, Orlando S, Daffonchio D, Puglia AM, Quatrini P. 2010. Rehabilitation of Mediterranean anthropogenic soils using symbiotic wild legume shrubs: Plant establishment and impact on the soil bacterial community structure. Appl Soil Ecol 46 (1): 1-8. DOI: 10.1016/j.apsoil.2010.05.007.

Mortimer, Peter E, Pérez-Fernández MA, Valentine, AJ. 2012. Arbuscular mycorrhiza maintains nodule function during external $\mathrm{NH}_{4}^{+}$supply in Phaseolus vulgaris (L.). Mycorrhiza 22 (3): 237-245. DOI: 10.1007/s00572-011-0396-9.

Mosse B. 1973. Plant Growth Responses to vesicular-arbuscular mycorrhiza. IV. In soil given additional phosphate. New Phytol 72 (1): 127-136. DOI: 10.1111/j.1469-8137.1973.tb02017.x.

Motaghi S, Nejad TS. 2014. The effect of different levels of humic acid and potassium fertilizer on physiological indices of growth. Int $\mathbf{J}$ Biosci 5 (2): 99-105. DOI: 10.12692/ijb/5.2.99-105.

Nadeem SM, Ahmad M, Zahir ZA, Javaid A, Ashraf M. 2014. The role of mycorrhizae and plant growth-promoting rhizobacteria (PGPR) in improving crop productivity under stressful environments. Biotechnol Adv 32 (2): 429-48. DOI: 10.1016/j.biotechadv.2013.12.005.

Oldroyd GED, Murray JD, Poole PS, Downie JA. 2011. The rules of engagement in the legume-rhizobial symbiosis. Annu Rev Genet 45: 119-144. DOI: 10.1146/annurev-genet-110410-132549.

Omar SA. 1997. The role of rock-phosphate-solubilizing fungi and vesicular-arbuscular-mycorrhiza (VAM) in growth of wheat plants fertilized with rock phosphate. World J Microbiol Biotechnol 14 (2): 211-218. DOI: 10.1023/A:1008830129262.

Plenchette C, Fortin JA, Furlan V. 1983. Growth response of several plant species to mycorrhiza in a soil of moderate P fertility.1. Mycorrhizal dependency under field conditions. Plant Soil. 70: 191-209. DOI: $10.1007 / \mathrm{bf02374780.}$

Prayudyaningsih R. 2014. Growth of Alstonia scholaris, Acacia auriculiformis, and Muntingia calabura inoculated by Arbuscular Mycorrhizal Fungi on the media of ex-limestone mining. Wallacea For Res 3 (1): 13-23. DOI: 10.18330/jwallacea.2014.vol3iss1pp1323. [Indonesian] 
Puppo A, Groten K, Bastian F, Carzaniga F, Soussi M, Lucas MM, de Felipe MR, Harrison J, Vanacker H, Foyer CH. 2005. Legume nodule senescence: roles for redox and hormone signaling in the orchestration of the natural aging process. New Phytol 165 (3): 683701. DOI: 10.1111/j.1469-8137.2004.01285.x.

Sindhu PV, Kanakamany MT, Beena, C. 2016. Effect of organic manures and biofertilizers on herbage yield, quality, and soil nutrient balance in Indigofera tinctoria cultivation. J Trop Agric 54 (1): 16-20.

Smith SE, Gianinazzi-Pearson V. 1988. Physiological interactions between symbionts in vesicular-arbuscular mycorrhizal plants. Annu Rev Plant Physiol Plant Mo Biol 39 (1): 221 244. DOI: 10.1146/annurev.pp.39.060188.001253.

Smith SE, Read DJ. 2010. 3rd Ed. Mycorrhizal Symbiosis. Academic Press, New York.

Streeter J. 1988. Inhibition of legume nodule formation and $\mathrm{N}_{2}$ fixation by nitrate. Crit Rev Plant Sci 7 (1): 1-23. DOI: 10.1080/07352688809382257.
Sulakhudin, Suswati D, Hatta M. 2017. The effect of ameliorants on improvement of soil fertility in post gold mining land at West Kalimantan. J Degrad Mining Lands Manag 4 (4): 873-880. DOI: 10.15243/jdmlm.2017.044.873.

Surtiningsih T, Farida, and Nurhariyat T. 2009. Bio fertilization of Rhizobium Bacteria on Soybean (Glycine $\max$ (L) Merr.). Berk. Penelitian Hayati 15: 31-35. DOI: 10.23869/bphjbr.15.1.20097. [Indonesian]

Tawaraya K, Tokairin K, Wagatsuma T. 2001. Dependence of Allium fistulosum cultivars on the arbuscular mycorrhizal fungus, Glomus fasciculatum. Appl Soil Ecol 17 (2): 119-124. DOI: 10.1016/S09291393(01)00126-3.

Via VD, Zanetti ME, Blanco F. 2016. How legumes recognize rhizobia. $\begin{array}{lllll}\text { Plant Signaling Behav } 11 & \text { (2): e1120396. DOI: }\end{array}$ 10.1080/15592324.2015.1120396 